Environment Conservation Journal 14(3)17-22, 2013

ISSN 0972-3099 (Print) 2278-5124 (Online)

Abstracted and Indexed

\title{
Length weight relationship and Fulton's condition factor of Macrobrachium assamense peninsularie in Khoh tributary of Ram Ganga from Garhwal Himalaya, Uttarakhand, India
}

\author{
Anita Rawat Rana and Koshal Kumar
}

Received: 22.03 .2013

Revised: 17.07.2013

Accepted: 27.08.2013

\begin{abstract}
Macrobrachium assamense peninsularie length-weight relationship and Fulton's condition factor was studied in Khoh tributary of Ram Ganga in the Garhwal Himalaya region of Uttarakhand for the period of one year from March 2009Feb 2010. A strong positive relationship was observed between the length and weight in both the sexes (male and female) $(b<3)$. Also when data was pooled, the growth was allometric $(b<3)$. The values obtained from the length/weight relationship (LWR) showed that there was a high and significant correlation between the total length and weight after using the $t$-test for the significance of correlation. The highest correlation coefficient ' $r$ ' $=0.94$ i.e strong association between length and weight was observed. This means that as the length of the prawn increases the weight increases in the same proportion. Coefficient of determination $\mathbf{r}^{2}$ was also high $(0.88)$ which indicated that the model used for the analysis fits the data, confirming the fitness of the model. The Fulton's condition factor " $K$ " was recorded highest $(K=2.0603)$ in March and lowest $(K=1.6195)$ in May in Male while in female, the condition factor $(K=2.1038)$ was highest in August and lowest $(K=1.5345)$ in October. The condition factor " $K$ " ranges from 1.6195 to 2.0603 in male and 1.5345 to 2.1038 in female. It means the condition factor was sex and season dependent. The difference in condition factors in male and female may be attributed to the presence of ovigerous female, environmental conditions and changes in feeding intensity.
\end{abstract}

Keyword: Fulton's condition factor, Garhwal imalaya, Khoh tributary, length- weight relationship, Macrobrachium assamense peninsularie

\section{Introduction}

The fresh water prawn Macrobrachium assamense peninsularie belongs to Phylum: Arthropod, Class: Crustacea, Order: Decapoda, Family: Palaemonida, Genus: Macrobrachium, Species: assamense peninsularie (Tiwari, 1955) found in the foot hill region of the Uttarakhand.Average size ranges from 25-75 $\mathrm{mm}$ in length, color having either blue or brown, creamish with pinkish spot on the body and often bottom feeder. These are commonly known as "Jingoor" in the local language.The body is divisible into three main divisions: the head, thorax and abdomen. The head and thorax are joined to form cephalothorax which carries mandibles, flagella, rostrum and eye containing a stalk and has five pair of walking legs. Rostrum is slightly slender having dorsal 5-10 teeth and 0-3 in below.

Author's Address
Department of Zoology, Pt. L.M.S. Govt. Post Graduate
College (An Autonomous College) Rishikesh, Dehradun
Email: dr.anitaarawat@gmail.com

Copyright by ASEA

All rights of reproduction in any form reserved
The abdomen has six body segments with the last segments bearing uropods or telson. The other five segments bear swimming apparatus known as swimmerets.Their food consists of macro zoobenthos, debris and dead and decay leaves and other algal bodies. A definite feature of Macrobrachium is that the second walking legs are modified to form chelae. The mature males are considerably larger and heavier than females and second walking leg is much thicker. The cephalothorax is also larger in male than female while abdomen is narrower in the female. The genital pore of the male is between the bases of the fifth walking leg (New and Singholka, 1982) and in the female the genital pore lie at the base of the third walking legs. The pleopod of female forms a brood chamber in which the eggs are carried between the laying and hatching. A ripe ovigerous female can easily be identified because the ovaries 
can be seen as large orange colored mass occupying a large portion of the cephelothorax. Fresh water prawns of the genus Macrobrachium are cherished by the people living nearby the water body in Himalayan region. They are used as condiments in the preparations of food because of their high protein value (Umon and Bassir, 1997; Deekae and Idoniboyeobu, 1995).It has been observed that there is significant reduction of the natural stocks of these fresh water prawns in Khoh. This may be due to the unfriendly fishing methods used by local people. The fresh water prawn $M$. assamense peninsularie is exploited in Khoh tributary of river Ganga in the Garhwal region of Himalaya. Therefore understanding the biology, environmental parameters and population structure is essential to optimize production from the wild and the study would provide basic line data for management decision of the species in the area and other fresh water bodies. Yet there is no reports on the population biology of these species in the area.Length weight relationship of fresh water prawn is important fishery management tool. It's importance is pronounced in assessing the average weight at given length group (Beyer, 1987) and in assessing the relative well being of the fish population (Bolger and Connoly, 1989; Abowei et al., 2008), condition factor has been used as an index of growth and feeding intensity and reproductive cycle (Fagade, 1997; Abowei et al. 2009). Till date no work has been done on the length-weight relationship of $M$. assamense peninsularie in Khoh tributary. A study on the length- weight and condition factor from Khoh tributary provides for the management of these crustacean fishery especially fresh water prawns.

\section{Material and methods}

Study area: The study was carried out in Khoh tributary of Ram Ganga river in Garhwal Himalaya region of Uttarakhand in India for a period of one year from March 09-Feb10. The Khoh is a spring fed tributary of Ram Ganga river and is located in between longitudes 78 $32^{\prime}$ '19' $\mathrm{E}$ and latitudes $29^{\circ} 45^{\prime} 26^{\prime \prime} \mathrm{N}$ in Pauri District of Uttarakhand, India. The tributary originates from the Kertikhal and Goomkhal and flows downwards through Dadamandi. Dadamandi is a thickly populated station. The water temperature ranges from 20- $26^{\circ} \mathrm{C}^{\prime}$ alkalinity $50-100 \mathrm{ppm}$ and water velocity $0.30-0.50 \mathrm{~m} / \mathrm{sec}$. Due to the vast quality of macrozoophyte habitation the tributary hence provide good fishing opportunity for the residents. The area is economically important and rich in biodiversity. Fishing is one of the major activities going on along the tributary because it harbors the fishes of different species.

Specimen sampling: The samples were collected from the seven sites along the tributary: namely Matiyali, Hanumanti, Dugada, Aeta, Amsour, Lalpul, Sidhwali. Selection of the sites was purposefully based on the availability of specimens, ecological zonation and on the basis of variation in altitude ranging from 400-900 masl. The collection was done from all the selected sites in the day time with the help of sieve and some time by hand picking from the grassy vegetation and under the crevices of stony area in the stagnant water, about 10 square feet area was selected in each site. The collected specimens were sorted for male and female, female were later separated in berried (ovigerous) and non-berried (non-ovigerous). The collected prawn samples were then preserved $5 \%$ formalin and transported to the Department of Zoology, Govt. P. G College, Rishikesh Dehradun and kept for the further study in the laboratory. The identification was done by use of the standard keys of Tiwari (1955) and Holthius (1965 and 1978). In monthly collected each specimen, measurements viz; the total length and carapace length was measured with the help of digital vernier caliper to nearest $0.1 \mathrm{~mm}$ and then weighed with (MAC) digital balance to the nearest $0.01 \mathrm{gm}$. The length weight relationship of $M$. assamense peninsularie was estimated using linear equation (Pauly, 1983; Wahua, 1999). The technique is incorporated in the FAO ICLARM, stock assessment tool (FiSAT) (Gayanilo and Pauly, 1997) which is used in fisheries.The length weight relationship was obtained from the relationship.

$$
\mathbf{W}=\mathbf{a} \mathbf{L}^{\mathbf{b}} \text { (Pauly, 1983; Sparre et al., 1989) }
$$

$$
\begin{aligned}
& \text { Where: } \\
& \mathrm{W}=\text { Weight of prawn }(\mathrm{g}) \\
& \mathrm{L}=\text { Length of prawn }(\mathrm{mm}) \\
& \mathrm{a}=\text { Intercept } \\
& \mathrm{b}=\text { Slope }
\end{aligned}
$$


The ' $a$ ' ' $b$ ' values were obtained from a linear regression of length and weight of these prawns. The linear equation was fitted on the monthly basis for male and female. Analysis of covariance (ANNOVA) was employed to test the significance of difference between regression coefficient ' $b$ ' at 5 $\%$ level of both the sexes (Snedecor and Cochran, 1967; Hoda, 1976). The coefficient of correlation (r) is a quantitative measure of the correlation between two variables. The equation for getting Karl Pearson's coefficient (r)

$$
r=\frac{n \sum x y^{\prime}\left(\sum x\right)\left(\sum y\right)}{\sqrt{n\left(\sum x^{2}\right)-\left(\sum x\right)^{2}} \sqrt{n\left(\sum y^{2}\right)-\left(\sum y\right)^{2}}}
$$

Where:

$$
\begin{aligned}
& X=\text { Variable } X \text { (length) } \\
& \underline{X}=\text { Mean of variable } X \\
& Y=\text { Variable } Y \text { (weight) } \\
& \underline{Y}=\text { Mean of variable } Y \\
& r=\text { coefficient of correlation between } \\
& \text { variable } X \text { and } Y \\
& S_{X}=S D \text { of variable } X \\
& S_{Y}=S D \text { of variable } Y
\end{aligned}
$$

Condition factor is the plumpness of a shrimps. It determines the well being of the particular shrimps in a particular water body Deekae et al., (2010). The condition factor of the prawns was estimated from Fulton's condition factor (CF) as suggested by Enin, (1994).

$$
C F=\frac{W X 100}{T L^{3}}
$$

Where:

$$
\begin{aligned}
& \text { CF = Fulton's condition factor } \\
& \text { W = Means of weight }(\mathrm{g}) \\
& \mathrm{TL}=\text { Mean of total weight }(\mathrm{mm})
\end{aligned}
$$

Fulton's condition factor was estimated for each month during the study period

\section{Results and Discussion}

The length weight relationship of male and female $M$. assamense peninsularie from Kho tributary are shown in Fig.1, 2, 3. A strong positive relationship was observed between the length and weight for female, male and in both sexes. The value of 'a.' ' $b$ ' and ' $r$ ' are given in the Table 1. The values of ' $b$ ' were not greater than 3 for male and female as well as in pooled.

Table 1: Parameters of length weight relationship of $M$. assamense peninsulare in Khoh tributary

\begin{tabular}{|l|l|l|l|l|l|}
\hline Sex & $\mathbf{n}$ & $\mathbf{a}$ & $\mathbf{b}$ & $\mathbf{r}$ & $\mathbf{r}^{2}$ \\
\hline Male & 111 & -3.367 & 1.31 & 0.96 & 0.92 \\
\hline Female & 128 & -1.78 & 0.736 & 0.88 & 0.77 \\
\hline Pooled & 239 & -2.75 & 0.979 & 0.94 & 0.88 \\
\hline
\end{tabular}

n=number of specimens, a=regression co-efficient, $b=$ regression co-efficient, $r=$ correlation co-efficient

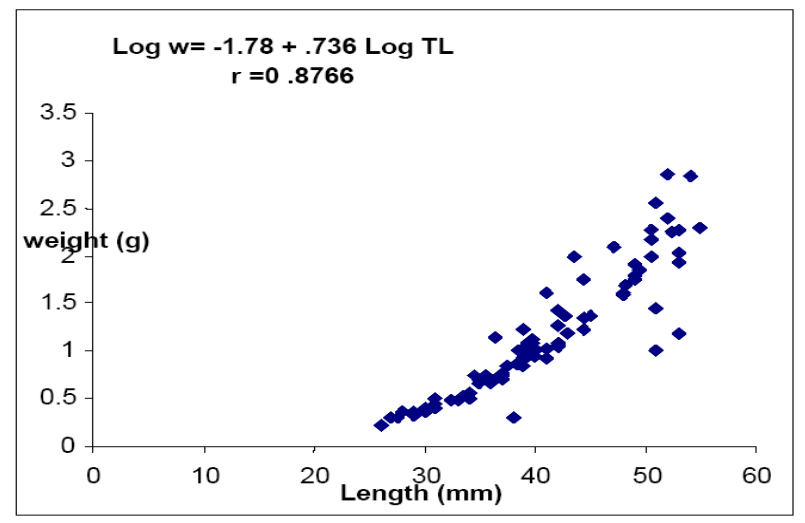

Fig.1 Length weight relationship in female Macrobrachium assamense peninsularie in Khoh tributary

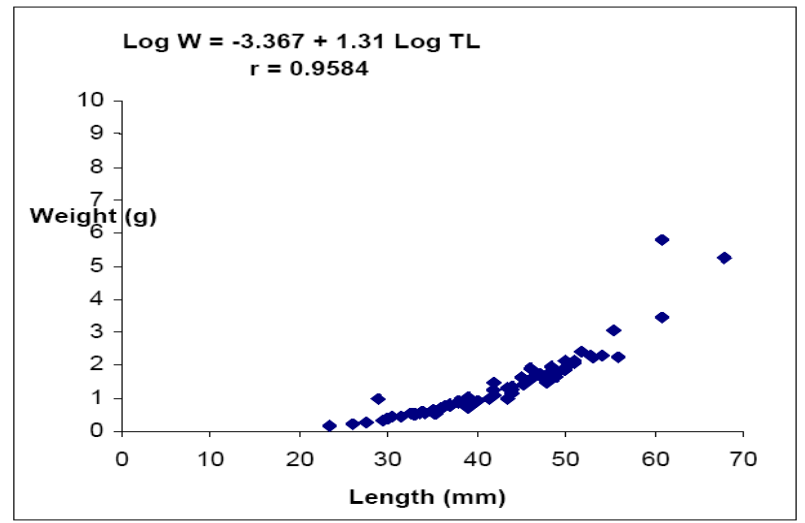

Fig.2 Length weight relationship in male $M$. assamense peninsularie in Khoh tributary 


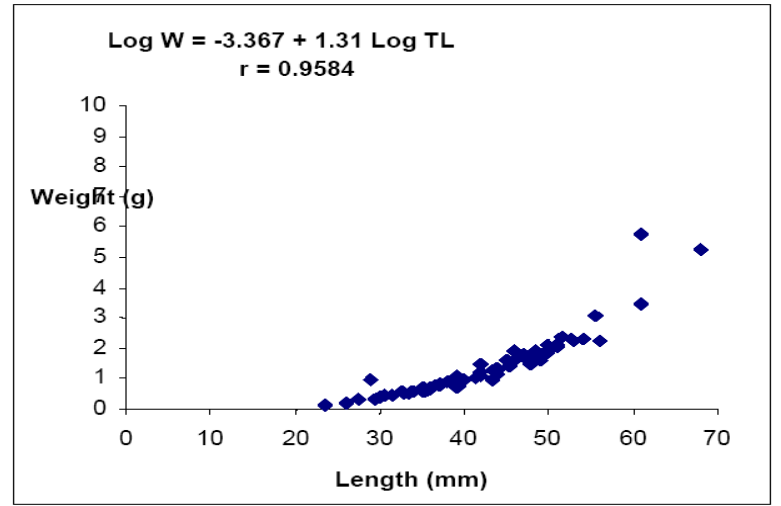

Fig3. Length weight relationship in both sexes of Macrobrachium assamense peninsularie in Kho tributary

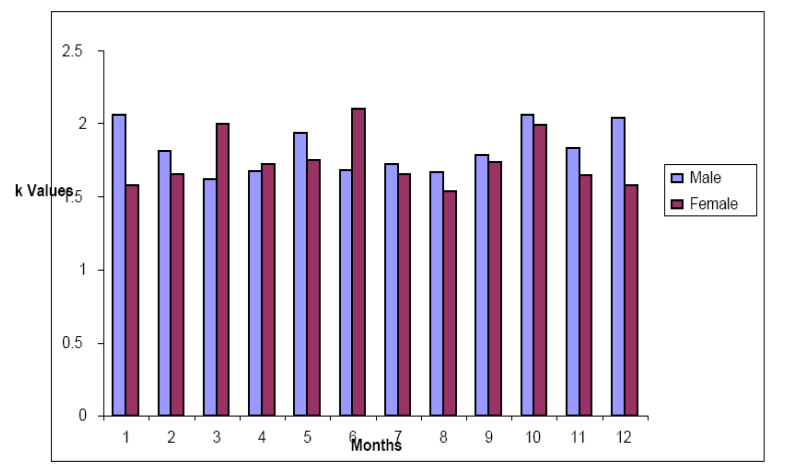

Fig.4 Month wise condition factor of $M$. assamense peninsularie in Khoh tributary

Hence growth is allometric in individual sex as well as in pooled (b value is not greater than 3 ). The result of the Fulton's condition factor " $K$ " determined for these prawns in Khoh tributary are shown in Fig 4. In male the Fulton's condition factor " $K$ " was recorded highest $(\mathrm{K}=2.0603)$, and lowest $(\mathrm{K}=1.6195)$, and in female highest $(\mathrm{K}=2.1038)$ and lowest $(\mathrm{K}=1.5345)$ was recorded monthly during the study period. The condition factor "K" ranges from 1.6195 to 2.0603 in male and 1.5345 to 2.1038 in female. The value obtained from the length weight relationship (LWR) of fresh water prawns $M$.assamense peninsularie in Khoh tributary in Garhwal Himalaya showed that there was a high and significant correlation between the total length and weight. The ' $b$ ' value (0.736-1.31) and correlation coefficient ' $r$ ' value (0.88- 0.96) obtained in this study are within range by Enin, (1994) and Marioghae, (1982). When both sexes of prawn (male and female) M. assamense peninsularie in Khoh tributary were considered the ' $b$ ' value was below 3 which indicate the growth is allometric. Deekae and Abowei (2010) reported allometric growth pattern of growth in Macrobrachium macrobrachion. The slight variation in the value of ' $b$ ' and ' $r$ ' is understandable because length-weight relationship of the species could vary according to locality and season (Medina-Reyha, 2001; Prasad, 2001). The highest correlation coefficient ' $r$ ' of 0.94 obtained in this study showed that there is strong association between length weight. This means that as the length of the prawn increases the weight increases in the same proportion. Coefficient of determination $\mathrm{r}^{2}$ was also high (0.88) which indicated the model used for the analysis fits the data, confirming the fitness of the model. The mean condition factor ' $\mathrm{K}$ ' obtained from this study was both sex and season dependent. There were significant variations between sexes. The condition factor difference reported in male and female may be due to the presence of ovigerous females, influence of environmental conditions and also changes in feeding intensity. Similar observations by Braga (1986) showed that values of condition factor vary according to seasons and environmental conditions.Branco and Masunari, (2000) reported difference in condition factors of male and female Callinectes donae from Conceicao lagoon system, Santa catarinaa, Brazil. They observed that it was probably due to higher weight of the female gonads of the crabs.Similar observations have been reported in some species of fish by earlier workers (Dhanze et al., 2005; Barua et al., 1988; Jhingran, 1972).

\section{Conclusion}

- M. assamense peninsularie growth in Kho tributary for both sexes was allometric.

- The correlation coefficient ' $r$ ' was high, an indication of a strong association between length weight. This means that as length increases the weight increases in the same proportion.

- The mean condition factor " $K$ " obtained from this study was both sex and season dependent.

- M. assamensie peninsularie from Kho tributary was in good and stable environment condition. 


\section{References}

Abowei, J. F. N. 2009 a. The abundance, condition factor and length weight relationship of Cynoglossus senegalensis (Kaup, 1885) from Nkoro River Niger Delta Nigeria Adv. J. Food sci. Technol., 1(1): 56-61.

Abowei, J. F. N. 2010 b. The condition factor, length weight relationship and abundance of Illish Africana (Block, 1795) from Nkoro River Niger Delta Nigeria. Adv. J. Food sci. Techno. 2(1)16-21.

Abowei, J. F. N. and George, A. D. I. 2009. A study of the length-weight relationship and condition factor of Callinectes amicola (De Rochebrune, 1883) from Okpoka Creek, Niger Delta, Niger. Int J. Anim. Vet. Adv., 1 (2): 66-72.

Abowei, J. F. N., George, C., Tiwari, C, Deekae, S. N.,George, D.N., Amakiri, E. 2008. A study of length Weight relationship and condition factor of Psedotolithus elangatus (Browdich, 1825) from Bonny Estuary, Niger Delta, Niger. Int. J. Trop. Agr. Food. Sys. 2 (3-4) 249254.

Barua, G., Mollah,M.F.A.,Quaddus,M.A and slam ,M.A 1988, Length-weight relationship and Growth condition of Clarius batrachus(Linn) in different months and Sexes .Bangladesh J.Fish.11(2): 21-34.

Beyer, O. 1987. On length weight relationship computing the mean weight of the fish of a given length class. Fish byte (I): 11-13

Bolger, T. and Connoly, P. L 1989. The selection indices for the measure and analysis of fish condition. J. Fish Biol., 30:171-182.

Braga, F.M.S. 1986. Estudo entre o factor de condicao e relacao peso/comprimento para alguns peixes marinhos. Rev. Brasil. Biol. 46(2):339 346.

Branco, J. O and S. Masunari 2000. Reproductive ecology of the blue crab, Callinectes donae, Smith 1869, in the Coneicao Lagoon system, Santa Catarina Isle, Brazile Zool., 17(3): 51-70.

Deekae, S. N and J. F. N Abowei 2010. Macrobrachium macrobrachion (Herklots, 1851) Length-weight relationship and Fulton's condition factor in Luubara creek, Ogoni Land, Niger Delta, Nigeria. Int. J. Anim.Veter. Adv., 2(4):115-162.

Deekae, S. N and T. I. E. Idoniboye-Obu 1995. Some aspect of commercial important mollusks and crabs of the Niger Delta, Nigera. Environ.Ecol., 13(1):136-142.
Dhanze,R.,Sharma,I.and Dhanze,J.R. 2005.Length weight relationship of golden Mahaseer Tor putitora(Ham) from Western Himalayas.J.Inland Fish.Soc. India, 37(2);6062.

Enin,U. I 1994. Length-weight parameters and condition factor of two West African Prawns Trop. 27(2);121-127.

Rev. Hydrobiol.

Fagade, S. O. 1979. Observation on the biology of species of Tilapia from Lagos Lagoon. Bull. De. 1 F.A.N., 419(A3):60-72.

Gayanilo, F. C and D. Pauly 1997. FAO-ICLARM Stock Assesment Tools (FiSAT). FAO Computerised Information Series (fisheries) No. 8, Rome, pp 262.

Holthius, L. B. 1978. A collection of Decapod Cruatacea from Sumba, Lesser Sanda Islands Indonesia; Zool. Verh. 162, 55 .

Holthuis, L. B and J. R. Roas 1965. List of shrimps and prawns of economic value. FAO.Fish Tech. 52; 21 .

Hoda, S. M. S. 1976. Reproduction biology and length weight relationships of Thryssa dussumieri (Vol.) of the Pakistan Coast .J mar. Biol. Ass. India. 18: 272-287.

Jhingran, A.G 1972.Fish and fishes of India.Hindustan publishing corporation (India). 3 ed. 15

Marioghae, I.E. 1982. Note on the biology and distribution of Macrobrachium vollenhovenii and Macrobrachium macrobrachion in Lagos Lagoon (Crustacea Decapoda, Paleamonidea) Review de Zoologie Africanie, 96(30): 493-508.

Medina-Reyha, C. E. 2001. Growth and emigration of white shrimp, litopenaeus vennamie in the Mar Muerto Lagoon, South Mexico. NAGA, ICLARM Q., 24 (1-2): 30-34.

New, M. B. and S. Singholka,1982. Fresh water prawns farming: Manual for the culture of Macrobrachium rosenbergii.FAO Fish. Tech. Pp., 225:116.

Pauly, D. 1983. Some simple methods for the assessment of tropical stocks. FAO Fish. Tech. pp: 234:52.

Prasad, G. 2001. Length weight relationship of Penacus monodon reared in semi-in-tensive culture system of Kerla, India. NAGA, ICLARM Q., 24 (1-2):16-17.

Snedecor .G. W and W. G Cochran 1967. Statical methods Oxford and IBH publis. Co., Calculat pp: 93. 
Sparre, P. E., Ursin and S. C Venema 1989. Introduction to
tropical fish stock assessment, part 1. Manual FAO Fisheries Technical pp. No. 306, 1 FAO Rome pp: 337.

Tiwari, K.K. 1955. Distribution of Indo Burmes fresh water prawns of genus palaemon Fabr. And it's bearing on the Satpura hypothesis; Bull. Nat. Inst. India 7: 230-239.
Umoh, I. B. and O. Bassir 1977. Lesser know sources of protein in some Nigerian peasant diets. Food Chem., 2:315-329.

Wahua, T. A. T., 1999. Applied Statistics for Scientific Studies. African Link Books, Owerri, pp: 356. 